\title{
South Africa's Application of the Gender Mainstreaming Strategy within the Water Resources Management of Rural Areas: Challenges and Limitations
}

\author{
Ms TM Ramoroka \\ Department of Development Planning \& Management, University of Limpopo \\ Millicent.Ramoroka@ul.ac.za
}

\section{Doi:10.5901/mjss.2014.v5n20p2517}

\section{Abstract}

Gender equality for rural development is currently envisaged as a necessary aspect for achieving efficient, effective and sustainable development projects. This aspect was inspired by the unexploited use of women as a resource especially for rural development. Based on the premise that men and women exhibit socially and culturally determined differences in behavior, roles and responsibilities; the Gender Mainstreaming Strategy holds that gender concerns in rural development including in all decisions regarding planning, design, location, operation and maintenance have to be based on the recognition of their differences. However, giving the pragmatic effects of the Gender Mainstreaming Strategy within the rural context has met with many challenges and limitations relating to structural issues, sustainability, the commitment of actors involved and the whole range of aspects of attitudinal change, both at individual and collective levels. This paper theoretically argues that the challenges and limitations involved in the application of the Gender Mainstreaming Strategy leads to virtual mismanagement of development projects within rural communities. Additionally, patriarchal tradition within rural areas has adverse effects on the application of the Gender Mainstreaming Strategy especially within the water resources management. One of the principles of this tradition is that women are household caregivers and men are leaders. However, women are the ones who have more knowledge on the natural resources in their areas and yet they are excluded or limited in their management. The paper therefore concludes that the genuine benefits of rural development would not be realized as long as the context within which the Gender Mainstreaming Strategy is applied remains traditional in terms of the gender status quo.

Keywords: Gender mainstreaming strategy; Water resources management; rural areas and South Africa

\section{Introduction}

Gender equality for rural development is currently envisaged as a necessary aspect for achieving efficient, effective and sustainable development projects and programmes (Boserup, 1989; Michael, 1998; Cornwell, 2004; Singh, 2006; Duarte, 2009; Kotze, 2009; Allwood, 2013; Baguma, Hashim, Aljunid \& Loiskandl, 2013; Walton, 2013; Reeves, 2014; Villamor, van Noordwijk, Djanibekov, Chiong-Javier \& Catacutan, 2014). This aspect was inspired by the unexploited use of women as a beneficial resource especially for rural development. Therefore, in order to realize the contribution of women in development projects and programmes, there is a need to develop and adopt a gender mainstreaming strategy. South Africa was among many countries which needed to deal with the gender disparities in most rural societies (Duarte, 2009). Apartheid together with the some people's traditions contributed to the gender inequalities in the country. Even though there were approaches to gender equality such as the gender equality approaches (Jacobson, 1992; Perrons, 2002; Aufhauwer \& Hafner, 2002; Arora-Jonsson, 2014), development-specific approaches (Hargreaves, 1997; Young, 2000; Cornwell, 2004; Bruno, 2006; Kwesiga \& Ssendiwala, 2006; Arora-Jonsson, 2014), and different approaches in gender equality (Rees, 1998; Verloo, 2001; Cornwell, 2004; Arora-Jonsson, 2014), little was changed between South African men and women. In 1994, during the Beijing Platform for Action, gender mainstreaming was considered to be the appropriate strategy to achieve gender equality amongst different communities, structures, various government departments and in all the development projects and programmes (Kwesiga \& Ssendiwala, 2006; Baguma et al., 2013). Post-apartheid, South Africa was in need of strategies to ensure gender equality and gender mainstreaming came to the rescue. However, the strategy was also accompanied by a number of challenges (Bennett, 1995; Ntsebeza, 2000; Rangan \& Gilmartin, 2002; Vlassoff \& Moreno, 2002; Morley, 2006; Bauer \& Burnet, 2013) which made it difficult to fully realize the benefits of the strategy.

It is in this context that this paper theoretically argues that the challenges and limitations involved in the application of the Gender Mainstreaming Strategy leads to virtual mismanagement of development projects within rural communities. The paper is divided into five sections including this introduction and the conclusion. The second section provides a brief 
discussion on how gender is related to water specifically in rural South Africa. The third section discusses the emergence of gender mainstreaming initiatives is South Africa and also the principles and measures of the strategy. The fourth section discusses the challenges and limitations that come with the planning and execution of the strategy with the water resources management of rural areas. The paper concludes that the genuine benefits of rural development, using the water resources management as a case would not be realized as long as the context within which the Gender Mainstreaming Strategy is applied remains traditional in terms of the gender status quo.

\section{Gender and Water in Rural South Africa}

Three fourths of mankind live on water drawn from outside their homes. The majority of the world's population lives in rural areas and most do not have water on tap. In Africa, women and girls spend 40 billion person-hours annually in collecting water (van Wijk, 1998; Baguma et al., 2013) and it has been noted that, in rural areas of South Africa, girls could spend up to 6-7 hours in water related activities like collecting the water, washing, cooking and others (Curtis, 1994). In order to understand the energy spent on water collection, one would not only look at time spent and transportation but also the ratio of carriers to consumers in a family (United Nations, 1991; Baguma et al., 2013). On average, women in Africa perform $90 \%$ of the total household work which includes processing food crops and providing household water and fuel (Cornwell, 2004). Two decades ago in South Africa, 9 out of 10 people in rural areas were carrying water from outside their yards and this has not changed much (Curtis, 1994). In households where women are working, their daughters collect the water for the households and do other household work sometimes with the help of their siblings. Men sometimes collect and carry water for usage by their livestock. In most cases, this water is only half of that used for domestic purposes (Lubis, 1998). As water collection is an activity particularly reserved for women and children in many countries, for a man to be seen even collecting water would bring shame. The gender differentiation in water collection and carriage is noticed as one considers that water carried for domestic usage is by women but the commercial scale of water is carried out by men (Curtis, 1994).

Water, as a natural resource has always been free and accessible from rivers, lakes and other related sources. Though women's work related to this natural resource has been heavy, its access has been free (Jacobson, 1993). In rural areas, women due to gendered division of work have always been involved in water collection, carriage and usage related activities as compared to men. Planning and the implementation involved in the construction of water-distribution systems has always been with men (Curtis, 1994; Baguma et al., 2013). Men determine the design and supervise the construction, whereas women are credited with determining water usage (UNESCO, 2000). In most cases, water problems in rural areas are not related to scarcity or quality alone, the main problem is when men's needs and standards provide a standard against which women's interests are measured and often minimised (Michael, 1998; Baguma et al., 2013). Putting the emphasis on women as water providers and users in the households alone without providing them a space in the planning process, would further obstruct their access to the general benefits attained in the public (Curtis, 1994).

\section{The Emergence of the Gender Mainstreaming Initiatives in South Africa}

After the Beijing Platform for Action in 1995 and the Johannesburg Plan of Implementation of the 2002 World Summit on Sustainable Development, the South African government agreed to support capacity building for water and sanitation infrastructure and services development, by ensuring that such infrastructure and services are gender-sensitive. Building on all these commitments at the end of the International Year of Freshwater in December 2003, the General Assembly proclaimed the International Decade for Action "Water for Life" from 2005 to 2015. The goals of the decade are a greater focus on water-related issues and the implementation of water-related programmes and projects whilst striving to ensure women's participation and involvement in the water-related development efforts (RSA, 1997). Based on the premise that men and women exhibit socially and culturally determined differences in behavior, roles and responsibilities; the Gender Mainstreaming Strategy holds that gender concerns in rural development including in all decisions regarding planning, design, location, operation and maintenance have to be based on the recognition of their differences. Seemingly, recognition of the different roles that men and women play in the water sector through the Gender Mainstreaming Strategy when designing projects and programmes can increase chances for sustainability. 


\subsection{South Africa's Principles of and Measures for Gender Mainstreaming Initiatives for Water Provision and Management}

Nowadays, gender mainstreaming is an essential global component in the policy field and in the strategic planning and management of water resources management (Mairhuber, 2002) and South Africa is no exception in this regard. In order to understand how South Africa hopes to minimize gender inequality, this section discusses its principles and measures of the Gender Mainstreaming Strategy. The section is divided into two subsections as follows:

\subsubsection{Principles of the Gender Mainstreaming Initiatives}

The Gender Mainstreaming Strategy is developed around the following principles (RSA, 2006):

- Equal participation of men and women as agents of change in the water resources management is essential to achieving gender equality.

- Individual and collective empowerment is central for men and women in order to meet their immediate practical needs as well as their long term strategic interests which lead to self-realisation.

- The strategy should at all times protect and promotes human rights for all.

- The strategy should address gender concerns in policy planning, programming, implementation and evaluation in all areas. Gender perspectives should be incorporated into the planning processes of all ministries and government departments.

- Partnership between men and women is encouraged by giving equal roles to men and women in creating more equal societies.

Additionally, there are six objectives that the Gender Mainstreaming Strategy has to meet. The objectives of the strategy are as follows (RSA, 2006):

1. Gender mainstreaming should be positioned at the centre of the water services delivery.

2. The Gender Mainstreaming Strategy should make water management and delivery of services more effective and sustainable.

3. Issues across all areas of water management should be defined in such a manner that gender differences can be diagnosed.

4. It requires that every effort be made to broaden women's participation at all levels of decision-making.

5. The strategy does not replace the need for targeted, women-specific policies and programmes/positive legislation, nor does it substitute for gender units or focal points.

6. Clear political will and the allocation of adequate and, if need be, additional human and financial resources for gender mainstreaming from all funding sources are important for the successful translation of the concept into practice.

In post-apartheid South Africa, development policies have reflected the broad trend in gender awareness (Rangan \& Gilmartin, 2002). After the African National Congress (ANC) won the political power, it outlined a strong commitment to gender and human rights in its approach to development. South Africa has promulgated a number of legislative and policy reforms that empower women and provide new ways to govern gender relations in the private and public sectors (Rangan \& Gilmartin, 2002). Consequently, women's empowerment and gender mainstreaming occupies the centre stage of the transformation process in all institutions, policies, procedures, practices and programmes of the government. There are a range of policies that inform gender mainstreaming in the provision of water services such as: the Constitution of the Republic of South Africa (RSA, 1996), the White Paper on a National Water Policy for South Africa (RSA, 1997a), the Department of Water Affairs and Forestry Gender Policy (DWAF, 1997), the South African National policy framework for Women's Empowerment and Gender Equality (RSA, 1997b) and Women Empowerment and Gender Equality Bill (RSA, 2013). In spite of the introduction of legislative and policy frameworks to influence the provision of water services, the involvement of women is still minimal when compared to that of men, who still handle the management decisions regarding water services especially in rural areas.

\subsubsection{Measures of the Gender Mainstreaming Initiatives}

In November 2005, the African Union's Solemn Declaration on Gender Equality was introduced. The declaration does not only support the spirit and letter of the UN Convention on the Elimination of all forms of Discrimination Against Women (CEDAW), but it also endorses the Protocol to the African Charter on Human and People's Rights on the rights of women 
(Duarte, 2009). South Africa stands out as a country which is progressing in terms of the representation of women in decision-making. For example, the African National Congress (ANC), which is the ruling party in South Africa, has taken a decision to practice equality within structures where it is involved. In 1990, the ANC held a conference in Durban where it introduced the $30 \%$ quota of women representation within its party. Those who did not agree to this argued that that the notion is a Western feminist idea and that it had no place in the African social and political life. Fortunately, the tradition of the ANC is that if a decision is reached, it has to be implemented (Duarte, 2009).

However, South Africa still faces the prospect of managing the reality that the emancipation of women goes beyond the right to vote during the elections. Women's emancipation is the continuation of a struggle to have women's rights recognized as human rights (Duarte, 2009). Human rights and the equality clause in the South African constitution are ignored when the places of power have to be shared and the historical role that a patriarchal society has designated to men is threatened. Even though the constitution entrenches equality, people still have beliefs, attitudes, myths and traditional practices that continue to inhibit the freedom of women. There is still elusiveness in women's full access to and control over productive resources to reduce poverty and the reason behind this are the long ruling structures and the nature of the country's economies (Rangan \& Gilmartin, 2002). When discussing the future of the country, men are in the majority, and women's voices are seldom heard. Most women understand the problems better but are seldom in the position to change and redirect resources towards solving the problems (Rangan \& Gilmartin, 2002). Women are only involved in the review process when the efficiency of the development projects and programmes is tested. This is an indication of a patriarchal mindset that needs to be changed (Duarte, 2009). When discussions are held on the right to equal pay for equal work in the International Labour Organisation (ILO), the voices of women are again not taken into consideration. The only recognized difference is the mobilization of people in favour of promoting the rights of women.

\section{Challenges and Limitations of the Application of Gender Equality in the Water Resources Management of South Africa}

In the context of the rural communities, the Gender Mainstreaming Strategy is divorced from the traditions and cultural beliefs of most villages. Singh (2007) argues that the Gender Mainstreaming Strategy does not represent a truly bottomup approach and it further raises the concern that if the strategy is contradictory to the traditions and cultural beliefs of the rural communities, then its objectives will never be achievable. The key challenge is making sure that gender constraints and gender mainstreaming become central in all development efforts, not as a marginalized issue (Kotze, 2009; Bauer \& Burnet, 2013; Arora-Jonsson, 2014). It is no longer considered radical for academics, policy-makers, and practitioners engaged in development to assert that their work has to be guided by gender equality, and more attention must be given to the needs of poor women (Rangan \& Gilmartin, 2002). Ensuring that gender mainstreaming is given attention in the development projects and programmes, still poses a challenge in the rural South Africa (Kotze, 2009). There are different degrees of success in its implementation and the relationship between macro (national and international), meso (organisational and departmental) and micro-level (groups and individuals) changes is still a problem (Morley, 2006).

The success of the application of the Gender Mainstreaming Strategy is demonstrated by its capacity to ensure participation of the under-represented groups, enabling them to take part in decision-making and in driving the process of change. South Africa, like many other countries, is facing a variety of apparently intractable challenges in the application of the Gender Mainstreaming Strategy. Even though there are policies, measures and initiatives to ensure that gender is mainstreamed in almost all the sectors, the challenge of practising what is on paper in real life still stands. In this section, the challenges that South Africa faces during the application of the Gender Mainstreaming Strategy are discussed as follows:

\subsection{Constitutional Contradictions}

There are three aspects to South Africa's post-apartheid Constitution that create contradictory conditions for pursuing gender equality (Rangan \& Gilmartin, 2002). These aspects are more noticeable in the former homelands and Bantustans which are still used as spaces of concentrated settlement for the majority of ethnic African populations (Hargreaves \& Meer, 2000). The first contradiction is that, although South Africa's Constitution has formally abolished the homelands and Bantustans, it continues to protect the status of traditional authorities who were appointed to control the areas. Through the traditional authorities, the apartheid government maintained indirect rule over African populations that were spatially concentrated in Bantustans (Rangan \& Gilmartin, 2002). The second contradiction is that while the postapartheid Constitution protects the status of the traditional authorities, it has introduced the Bill of Rights which is based on governance through elected representatives (Rangan \& Gilmartin, 2002). However, the traditional authorities in South 
Africa, still function on the principle of hereditary rule initiated by the past apartheid government. This means that the selected representatives of local governments struggle against the presence and powers of non-elected traditional authorities. However, both forms of governance are expected to function together at the sub-national level regardless of the contradictions (Bennett, 1995; Ntsebeza, 2000). The third contradiction is that while the Constitution promotes equal rights for both men and women, it simultaneously allows the exercise of traditional customary law in the former homelands. The problem with customary law is that it does not operate on the principle of gender equality and offers few formal means through which women's needs must be addressed (Rangan \& Gilmartin, 2002). The situations and conditions in the former Bantustans make it difficult to mainstream gender within the community development projects and programmes including in the water sector. Women tend to be excluded from the water resources management structures due to laws and traditions in their rural areas.

\subsection{Structural Challenges}

Official sanction is required in order for the Gender Mainstreaming Strategy to take root. The structural challenges include lack of gender policy guidelines, ad hoc decision-making, top-down management and lack of integration of the needs of both genders (Van den Brink \& Stobbe, 2014). This results in gender equality being an end-of-pipeline concern in many water resources management institutions in South Africa. There is a need to put in place an operational framework which will highlight the guidelines, rules, regulations, non-compliance measures and other important aspects related to gender equality (Kwesiga \& Ssendiwala, 2006; Bauer \& Burnet, 2013; Arora-Jonsson, 2014). In the initial process, decisions tend to be made in an ad hoc manner evolving as needs arise. Due to the lack of gender policy in the water resources management structures, some decisions are made because the necessary needs are realized with time (Kwesiga \& Ssendiwala, 2006; Van den Brink \& Stobbe, 2014; Reeves, 2014). The management tends to make decisions without a clear and true knowledge of what is happening on the ground. Their decisions are mostly based on assumptions and this top-down strategy results in the lack of ownership of the water resources. Furthermore, people involved in the water resources management tend not to have a sense of ownership of the water resources due to this top-down management strategy especially in rural areas. It is in this regard that the real needs and concerns of both men and women have not been fairly addressed. Thus, people do not have any influence on the planning, implementation and operation of the water resources.

\subsection{Creating Awareness and Understanding}

The concepts of gender and gender mainstreaming emerged from the feminist thinking which highlighted the social and cultural nature of the differences between men and women (Vlassoff \& Moreno, 2002; Allwood, 2013; Baguma et al., 2013; Walton, 2013; Blanco-Garcia, Sanchez-Antolin, \& Ramos, 2014, Villamor et al., 2014). The thinking slowly infiltrated into the development debates, including those of water resources management and development. However, gender issues have not been mainstreamed into the training of most water resources management professionals who have not been exposed to these concepts and their importance to water resources management (Boserup, 1989). Even though there has been progress in the past years in building a theoretical and practical basis for the incorporation of the Gender Mainstreaming Strategy into water resources management issues, empirical and other data demonstrating the importance of gender is still scarce and it is often overlooked (Byrne, 1996; Baguma et al., 2013; Blanco-Garcia, Sanchez-Antolin, \& Ramos, 2014). There is still a need for more complex analyses that will look at the relationship between water resources management and the gender equality issues. Furthermore, there is also a need to move from a diagnosis of gender-related problems to identifying solutions and interventions to address those problems. Water resources managers and policy makers often feel that gender inequalities are beyond their control and that they can only be addressed by profound societal change (Vlassoff \& Moreno, 2002). It is clear that broad societal change is needed, but there should be other ways in which the water sector can begin to incorporate gender equality issues into their policies and programmes. Most oftenly, the changes are small and simply, require an increased level of awareness and sensitivity to gender concerns and disparities (Vlassoff, 1997; Baguma et al., 2013).

\subsection{Epistemological Issues}

The philosophy of knowledge still poses a challenge. The view that gender is originally a Northern feminist issue continues to be used by some as an argument against integrating gender into the water sector (Vlassoff \& Moreno, 2002; Baguma et al., 2013; Van den Brink \& Stobbe, 2014; Reeves, 2014). Some people still take gender mainstreaming as 
women's issue and believe that women should be the ones leading the process (Kwesiga \& Ssendiwala, 2006; AroraJonsson, 2014). They tend to think that the Gender Mainstreaming Strategy is put in place in order to address women's issues only. It is within that context that the other sector of our population is left out and this result in their needs and concerns not being considered in the planning, implementation and operation of the water resources. There is also a belief that being a woman turns one into a gender expert (Kwesiga \& Ssendiwala, 2006; Baguma et al., 2013). In most cases women are the ones who drive the Gender Mainstreaming Strategy within the water resources management structures. The skills and expertise of men in this matter are left out without them being taken into consideration in the design, implementation and operation of the water resources. It is assumed that since domestic water use is the responsibility of women in most cases, women should be the participants of the Gender Mainstreaming Strategy (Singh, 2006).

\subsection{Actors/Change Agents}

Interested and committed actors or change agents are needed for the implementation and operation of the Gender Mainstreaming Strategy. Many people view this strategy as belonging to a few activists which presents a challenge of ownership of the strategy (Kwesiga \& Ssendiwala, 2006). The strategy tends not to be effective because some people feel and think that it is not their responsibility to make sure that it is successful. Another challenge which is related to the actors is the question as to how far the decision-makers, beyond the implementers, are committed to the required change (Howe, 1997; Bauer \& Burnet, 2013; Baguma et al., 2013; Van den Brink \& Stobbe, 2014). It should not only be the implementers of the strategy who are committed to the needed change which the strategy will bring but all those that are affected by the changes. The other challenge is the commitment to translate what has been agreed on in meetings into action. In some cases it tends to be very difficult to implement what has been agreed on due to lack of knowledge. The experience so far in the water resources management is that while a few of these have been converted to the course and act as expected, many still have to be persuaded and reminded if not forced into accepting the change (Kwesiga \& Ssendiwala, 2006). In most cases it is still men who attend most meetings as compared to women. While women tend to cite domestic workloads and inconvenience of time and venues as their reasons for not attending the meetings, in-depth investigation reveals heterogeneity among women members themselves. Female management committee members tend to ignore their own individual membership within the water resources management (Singh, 2006). They tend to think that membership in the committee is on the basis of household rather than on individual membership.

\subsection{Linking Gender to Training and Performance of Management Professionals}

Lack of understanding and appreciation of gender differentials and their implications for water resources management have a negative effect on the water services as a whole. Gender is not mainstreamed in most training and development of the water resources management professionals (Vlassoff \& Moreno, 2002; Bauer \& Burnet, 2013). Men are still trained for high levels positions (management) whereas women are trained for low levels positions (administration) within most water resources management structures (Hartigan, 2001; Bauer \& Burnet, 2013; Arora-Jonsson, 2014; Van den Brink \& Stobbe, 2014; Blanco-Garcia, Sanchez-Antolin, \& Ramos, 2014). In some of the water resources management structures, training is not provided for the professionals. Linking gender mainstreaming to performance appraisals is still a challenge with the water resources management. This results in gender mainstreaming not being taken seriously and not translated into practice. Indicators of gender sensitivity in work performance can be determined by whether the employees (mostly water committee members) have participated in the gender training course, performance in the course, use of gender sensitive language and the application of gender mainstreaming and analysis of the work (Vlassoff \& Moreno, 2002; Arora-Jonsson, 2014; Van den Brink \& Stobbe, 2014). While gender mainstreaming usually means providing greater opportunities to women in lower positions, it also means providing opportunities for men to work in traditionally female positions such as secretarial work within the water resources management (Hartigan, 2001)

\subsection{Implementation of the Strategy}

Most institutions have developed their Gender Mainstreaming Strategies and policies but their implementation still poses problems (Kotze, 2009; Baguma et al., 2013; Walton, 2013; Arora-Jonsson, 2014). Even though most institutions recognize and accept the importance of gender equality within the water resources management, there is a serious lack of institutional mechanisms to evaluate and monitor failures. Gender mainstreaming without accountability is nothing more than just a technical exercise without any long term positive impacts (Mukhopadhyay, 2004). The structural gender 
inequalities and constraints cause practical and strategic constraints to effective gender mainstreaming (Clisby, 2005; Baguma et al., 2013; Blanco-Garcia, Sanchez-Antolin, \& Ramos, 2014). The process of gender mainstreaming is characterized by very few activities instead of a coherent and integrated process (Moser \& Moser, 2005; Walton, 2013). Even though most institutions have developed and introduced a gender policy, major challenges exist at the level of implementation where in most cases policy commitments and documents disappear into thin air (Kotze, 2009; AroraJonsson, 2014). The other reasons for failure during the implementation stage are lack of staff capacity, organizational culture and attitudes which often includes resistance to gender equality, treating gender equality in isolation as a separate process without mainstreaming the gender issues and lack of ownership of the policy (Moser \& Moser, 2005). Gender mainstreaming should be treated as a process rather than as a goal, to build on what is already in place and address the overall constraints preventing the implementation of gender mainstreaming as a comprehensive strategy (Moser \& Moser, 2005).

\subsection{Sustainability Issues}

There is always the worry on how to sustain change, and in particular how to avoid backlash when applying the Gender Mainstreaming Strategy (Kwesiga \& Ssendiwala, 2006; Arora-Jonsson, 2014; Van den Brink \& Stobbe, 2014; BlancoGarcia, Sanchez-Antolin, \& Ramos, 2014; Villamor et al., 2014). All the related resources must be utilized in such a way that the gender related changes will at all times be easily sustained. Even after the implementation of the strategy, people should be able to operate within the changes that the strategy has brought about. In particular, the facilitation of the whole process is essential, in terms of the committed actors, financial and other related resources. Another issue relates to personnel, in terms of numbers and expertise to perform the function (Kwesiga \& Ssendiwala, 2006; Allwood, 2013; Bauer \& Burnet, 2013). The involved change agents seem to be few and not well experienced and trained in gender issues and this makes it difficult for them to apply the Gender Mainstreaming Strategy successfully. A more important issue is the need to keep the fire burning in all the stages of the implementation and operation of the strategy (Kwesiga \& Ssendiwala, 2006; Arora-Jonsson, 2014). Although it is important to get the management of the water resources owned by the community, there has to be a critical mass of people who believe in the usefulness of gender equality and who want to see it succeed. The challenge therefore, is how to periodically inject that required stimulant to make sure that the process of change does not stall. Experience has also shown that there is still a challenge in translating what is on paper into action in this regard.

\subsection{Cultural/Traditional Issues}

Rural communities are organized around institutional lines such as kinship, marriage and religion. These, in turn, critically relate in different ways to the natural resources available in the environment (Berkes, 1999; Baguma et al., 2013; Walton, 2013; Arora-Jonsson, 2014). South Africa also faces the problem of mainstreaming gender within traditional settings. The problem is that traditions and cultural beliefs, and, gender do not work together (Morley, 2006; Bauer \& Burnet, 2013; Walton, 2013). Moreover, traditional knowledge and water resources management systems have always been found to be gendered, with differences between women and men with respect to needs, roles and natural resources (Berkes, 1999; Singh, 2000; Baguma et al., 2013; Reeves, 2014). Several barriers prevent women in rural areas from reaching more meaningful levels of participation even when they are registered members of the water resources management committee (Evertzen, 2001; van Wijk-Sijbesma, 1995; World Bank, 1996). Additionally, there is still a belief that men do a better job than women; that is why in most cases women are not selected as committee members or even promoted as men are in the working environment (Morley, 2006). Two types of factors can be identified as responsible for such a situation. Firstly, there are individual factors which include a disinterest in political decision-making processes, lack of confidence, low levels of education and professional experience outside the household and lack of leadership experience. Secondly, there are institutional factors that include lack of support from husbands or family with respect to domestic responsibilities, religious and patriarchal norms and values that may exclude women from public life, all of which may influence their practical limitations such as their availability to attend meetings and be present at particular locations (Singh, 2006).

\subsection{Attitudinal Change}

The core challenge for everyone is how to stimulate attitudinal change to embrace new approaches, especially at a personal level (Kwesiga \& Ssendiwala, 2006; Baguma et al., 2013; Bauer \& Burnet, 2013; Walton, 2013; Van den Brink \& 
Stobbe, 2014; Villamor et al., 2014). The experience therefore, is that one needs personal commitment as an actor in the gender mainstreaming process, in order to relate theory with practice. This simply implies that the attitudes and stereotyping arising from the socialization process have been re-oriented by the individual. In most institutions, change is required in the operations of water resources as a whole. A commitment to an enabling working environment for both men and women is needed. This includes changes in language, attitudes and behaviour (Vlassoff \& Moreno, 2002). It starts with an individual accepting and being willing to work according to the strategy before the entire institution is affected (Kwesiga \& Ssendiwala, 2006). If gender mainstreaming is to become a reality, and not just rhetoric, clear commitment is needed mostly from senior management in the water sector. There should also be resource allocations to undertake capacity building and other necessary changes at all levels (Vlassoff \& Moreno, 2002).

\subsection{Unintended Consequences of the Gender Mainstreaming Strategy in the Water Resources Management}

According to Imam $(1997,3)$, development theorists and practitioners have always assumed that policies are automatically gender-neutral, accommodate both men and women fairly and equally and do not discriminate against either of them in any way. However, gender policies are often gender-blind, lacking awareness of distinction of gender and also refusing to acknowledge it. The theories and policies which insist that they are gender-neutral may be genderbiased, by basing their assumptions on consideration of one gender, usually men (Imam, 1997; Allwood, 2013; Baguma et al., 2013; Arora-Jonsson, 2014; Blanco-Garcia, Sanchez-Antolin, \& Ramos, 2014; Van den Brink \& Stobbe, 2014; Villamor et al., 2014). There have been a number of false assumptions that were made about how development occurs and about women's role in the society and their place in development, especially within the water sector (Cornwell, 2004). It is argued that the government's water development policies lead to sustainable water services delivery that improves the standard of living of both men and women. These assumptions fail to realize that men and women are just social constructions and that the two occupy different positions in the society. Gender identity determines the ways in which they are to participate in different positions in the society and within the water resources management (Cornwell, 2004; Allwood, 2013; Baguma et al., 2013). This identity also shapes and determines the roles and activities that the society approves as appropriate and the level of access those men and women would have to services and resources. It also determines their exclusion from such services and resources. The gender identity once again shapes the relations between men and women including their relative power in the water resources management (Imam, 1997; AroraJonsson, 2014; Blanco-Garcia, Sanchez-Antolin, \& Ramos, 2014; Villamor et al., 2014). The Western notions have defined households as nuclear institutions, which are made up of paid men and unpaid women (Cornwell, 2004). Due to the fact that women's labour is unpaid, it is therefore considered to be value-less labour. This also affects women's roles and outputs in the water resources management which are also overlooked (Sow, 1997; Baguma et al., 2013). The Water resources management is largely informed by the traditional and cultural beliefs about matters such as the nature of development, male-headed households and the nature employment (Cornwell, 2004).

\section{Conclusion}

After 1994, things started changing for the better as apartheid was abolished. Gender equality was introduced as a strategy which would solve the problems that apartheid created. Women were considered to be equal with men and that was also supported by the Bill of Rights and other policies which the government initiated. After the Beijing Conference in 1995, gender mainstreaming was identified as the best strategy to promote gender equality in all development projects and programmes and in all institutions and communities. The principles, measures and objectives of the South African Gender Mainstreaming Initiatives were identified for the easy implementation of the strategy. However, giving the pragmatic effects of the Gender Mainstreaming Strategy within the rural context has met with many challenges and limitations which are related to structural issues, sustainability, the commitment of actors involved and the whole range of aspects of attitudinal change, both at individual and collective level, among others. This paper theoretically revealed how the challenges and limitations involved in the application of the Gender Mainstreaming Strategy leads to virtual mismanagement of development projects within rural communities. Additionally, patriarchal tradition within rural areas has adverse effects on the application of the Gender Mainstreaming Strategy especially within the water resources management. One of the principles of this tradition is that women are raised to be household caregivers whereas men are trained as leaders. However, women are the ones who have more knowledge about the natural resources in their areas and yet they are excluded or limited in their management. The paper therefore concludes that the genuine benefits of rural development as seen from the water resources case would not be realized as long as the context within which the Gender Mainstreaming Strategy is applied remains traditional in terms of the gender status quo. The paper further 
recommends that women be released from or be assisted with their traditional household roles in order to give them time to participate in community related work such as water resources management.

\section{References}

Allwood, G. (2013) Gender mainstreaming and policy coherence for development: unintended gender consequences and EU policy. Women's Studies International Forum, 39, 42-52.

Arora-Jonsson, M. (2014) Forty years of gender research and environmental policy: where do we stand? Women's Studies International Forum. http://dx.doi.otg/10.1016/j.wsif.2014.02.009 (Accessed April 24, 2014).

Aufhauser, E. \& Hafner, S. (2002) Feminism and the new multi-scaling in employment policy. GeoJournal, 56(4), 263-260.

Baguma, D., Hashim, J.H., Aljunid, S.M. \& Loiskandl, W. (2013) Safe-water shortages, gender Perspectives, and related challenges in developing countries: the case of Uganda. Science of the Total Environment, 442, 96-102.

Blanco-Garcia, M., Sanchez-Antolin, P. \& Ramos, F.J. (2014) Are we close to achieve real equality under current policies? A view from the perspective of both education and employment. Procedia-Social and Behavioral Sciences, 116, 1468-1471.

Bauer, G. \& Burnet, J.E. (2014) Gender quotas, democracy, and women's representation in Africa: Some insights from democratic Botswana and autocratic Rwanda. Women's Studies International Forum, 41, 103-112.

Berkes, F. (1999) Sacred Ecology: Traditional Ecological Knowledge and Resources Management. Philadelphia: Taylor and Francis.

Bennett, T.W. (1995) Human Rights and African Customary Law. Cape Town: Juta Press.

Boserup, E. (1989) Population, the status of women and rural development. Population and Development Review, 15, 45-60.

Bruno, J.P. (2006) Feminist Approaches to Development and the Critique to Western Feminist Paradigm. Austin: University of Texas.

Byrne, B. (1996) Gender, Conflict and Development. Brighton: University of Sussex.

Clisby, S. (2005) Gender mainstreaming or just male-streaming? Experiences of popular participation in Bolivia. In Sweetma, F.P.C. (ed) Mainstreaming Gender in Development: A Critical Review. United Kingdom: Oxfam Publications.

Cornwell, L. (2004) Mainstreaming gender: imperatives for development studies. Journal of Development Administration, 34(1), 51-63.

Curtis, V. (1994) Women and the Transport of Water. London: Intermediate Technology Publications.

Department of Water Affairs and Forestry (DWAF) (1997) South Africa's Gender Policy. Government Printers, Pretoria.

Duarte, J. (2009) Gender machinery, gender protocols and women's reality. ANC Today, n.p.

Evertzen, A. (2001) Handbook for Gender and Local Governance, SNV. http://www.kit.nl/gcg/assets/images/Gender_and_Local_ Governance.doc. (20/07/2009).

Hargreaves, J. (1997) Women's sport, development, and cultural diversity: the South African experience. Women's Studies International Forum, 20(2), 191-209.

Hartigan, P. (2001) The importance of gender in defining and improving quality of care: some conceptual issues. Health Policy and Planning, 16, 7-12.

Howe, F. (1997) Promises to keep: trends in women's studies worldwide. Women's Studies Quarterly, 25(1), 404-423.

Imam, A.M. (1997) Engendering African Social Sciences: an introductory essay. In Imam, A.M., Mama, A. and Sow, F. (eds) Engendering African Social Sciences. Dakar Council for the Development of Economic and Social Research in Africa.

Jacobson, J.L. (1992) Gender Bias: Roadblock to Sustainable Development. Washington DC: World Watch Institute.

Jacobson, J.L. (1993) Closing the gender gap in development. State of the World Report. Washington DC: World Watch Institute.

Kotze, D. A. (2009) Linking human rights, gender equality and the MDGs. Journal of Development Studies, 39(1), 3-17.

Kwesiga, J. C. \& Ssendiwala, E.N. (2006) Gender mainstreaming in the university context: prospects and challenges at Makere University, Uganda. Women's International Forum, 29, 592-605.

Lubis, A.R. (1998) Water Watch: A Community Action Guide. Malaysia: Asia Pacific People's Environment Network.

Mairhuber, I. (2002) The Austrian NAP 2001 from a gender perspective. Final Report to the EC's Expert Group on Gender and Employment. Forschungs- und Beratungsstelle Arbeitwelt, Vienna. http://www.umist.ac.uk/management/ewerc. (22/05/2009).

Michael, B.P. (1998) The role of women in waste resources management, the Tanzanian case. A paper presented at Stockholm Water Symposium. Water: the Key to Socio-economic Development and Equality of Life. (August 10-13, 1998).

Morley, L. (2006) Hidden transcripts: the micro-politics of gender in Commonwealth University. Women's Studies International Forum, 29, 543-551.

Moser, A. \& Moser, C. (2005) Gender Mainstreaming Since Beijing: a Review of Success and Limitation in International Institutions. London: Oxfam Publications.

Mukhopadhyay, M. (2004) Mainstreaming gender or 'streaming' gender away: feminists marooned in the development business. IDS Bulletin 35(4). Brighton: IDS.

Ntsebeza, L. (2000) Traditional authorities, local government, and land rights. In Cousins, B. (ed) At the Crossroads: Land and Agrarian Reform in South Africa into the 21st Century. Cape Town: Programme for Land and Agrarian Studies.

Perrons, M. (1998) Gendered division in the New Economy: risks and opportunities. GeoJournal, 56(4), $271-281$.

Rangan, H. \& Gilmartin, M. (2002) gender, traditional authority, and the politics of rural reform in South Africa. Development and Change, 33, 4, 633-658.

Rees, T. (1998) Mainstreaming Equality in the European Union: Education, Training and Labour Market Policies. London: Routledge Press. 
Reeves, D. (2014) Putting women and gender in the frame-a consideration of gender in the global report on human settlements planning sustainable cities 2009. Habitat International, 43, 293-298.

Republic of South Africa (RSA) (1996) The Constitution of the Republic of South Africa. Pretoria: Government Printers.

Republic of South Africa (RSA) (1997a) South Africa's National Policy Framework for Women's Empowerment and Gender Equality. Pretoria: Government Printers.

Republic of South Africa (RSA) (1997b) White Paper on a National Water Policy for South Africa. Pretoria: Government Printers.

Republic of South Africa (RSA) (2006) National Implementation Strategy and Action Plan, 2006- 2010. Pretoria: Government Printers.

Republic of South Africa (RSA) (2013) Women Empowerment and Gender Equality Bill. Pretoria: Government Printers.

Singh, N. (2000) Understanding Identity and its Integration: A Study of the Mundos of Chotangpur. Delhi: University of Delhi.

Singh, N. (2006) Women's participation in local water governance: understanding institutional contradictions. Gender, Technology and Development, 10(1), 61-75.

Singh, N. (2007) Equitable gender participation in local water governance: an insight into institutional paradoxes. Water Resources Management, 22, 925-942.

Sow, F. (1997) The social sciences in Africa and gender analysis. In Iman, A.M., Mama, A. and Sow, F. (eds) Engendering African Social Sciences. Dakar Council for the Development of Economic and Social Research in Africa.

United Nations Education, Science and Cultural Organisation (UNESCO) (2000) A summary review of UNESCO accomplishments since the fourth world conference on women. Unit for the Promotion of the Status of Women and Gender Equality. New York: UNESCO.

United Nations (1991) The World's Women: Challenges of the Year 2000. New York: United Nations.

Van den Brink, M. \& Stobbe, L. (2014) The support paradox: overcoming dilemmas in gender equality programs. Scandinavian Journal of Management, 30, 163-174.

Van Wijk, C. (1998) Gender in water resources management, water supply and sanitation: poles and realities revisited. The Hague: IRC International Water and Sanitation Centre.

Van Wijk-Sijbesma, C. (1995) Gender in Community Water Supply, Sanitation and Water Resources Protection: A Guide to Methods and Techniques. Delft: IRC.

Verloo, M. (2001) Another Velvet Revolution? Gender Mainstreaming and the Politics of Implementation. IWM Working Paper No.5/2001. New York: IWM Publications.

Villamor, G.B., van Noordwijk, M.m Djanibekov, U., Chiong-Javier, M.E. \& Catacutan, D. (2014)

Gender differences in land-use decisions: shaping multifunctional landscapes? Current Opinion in Environmental Sustainability, 6, 128133.

Vlassoff, C. (1997) The gender and tropical diseases task force of TDR: achievements and challenges. Acta Tropica, 67, $173-180$.

Vlassoff, C. \& Moreno, C.G. (2002) Placing gender at the centre of health programming: challenges and limitations. Social Science and Medicine, 54, 1713-1723.

Walton, A.D. (2013) Just men? Towards the education of men for gender justice in a context of religiously legitimized patriarchy: a South African case study. International Journal of Education development, 33, 604-611.

World Bank (1996) Toolkit on Gender in Water and Sanitation. http://www-wds.worldbank.org/servlet/WDSContentServer/ WDSP/IB /2008/04/10/000094946_00121301483084/Rendered/PDF/multi_page.pdf. (10/04/2008).

Young, K. (2000) Gender and development. In Visvanathan, N. (ed) Women, Development and Gender Reader. London: Zed Books. 